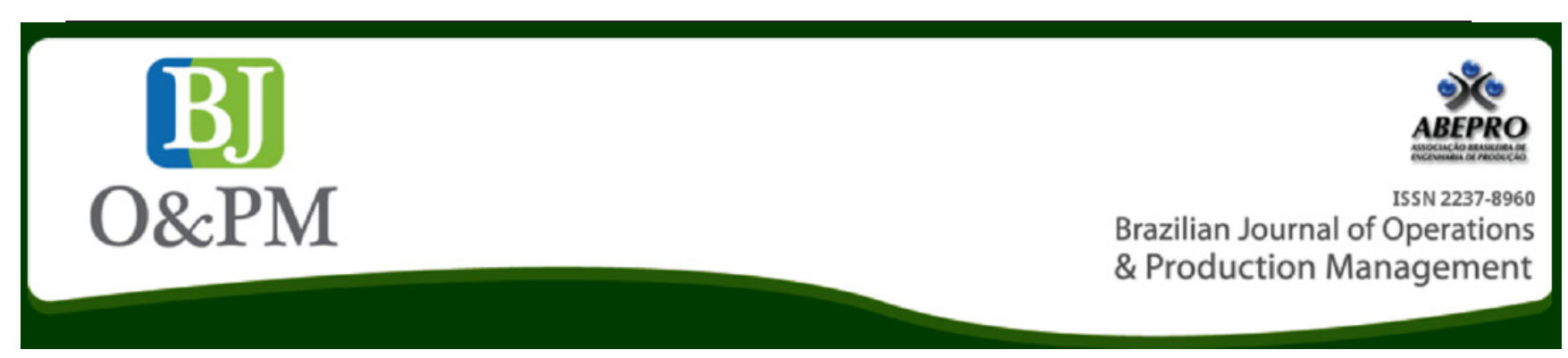

\title{
AN EXPLORATORY SURVEY ON THE TOPIC INTEGRATED MANAGEMENT SYSTEMS
}

\author{
Andréa Cristina Trierweillera; Antonio Cezar Bornia ; Maria Fernanda Sobierajski Gisia; Débora Spenassato ; \\ Blênio César Severo-Peixec; Maurício José Ribeiro Rotta ${ }^{a}$
}

\author{
${ }^{a}$ Federal University of Santa Catarina (UFSC) - Florianopolis, SC,Brazil \\ ${ }^{b}$ Federal University of Rio Grande (UFRGS) - Porto Alegre, RS, Brazil \\ ${ }^{\mathrm{C}}$ Federal University of Paraná (UFPR) - Curitiba, PR, Brazil
}

\begin{abstract}
Purpose - This article aims to analyse publications about Integrated Management Systems (IMS) and identify research opportunities. We verify that the number of international Management System Standards has grown rapidly such as: Quality Management (ISO 9001), Environmental Management (ISO 14001), Occupational Health and Safety Assessment Standard (OHSAS 18001), and Corporate Social Responsibility (AA1000). Their structures are similar and can be combined in a single management model, organized with a basis in the P (Plan), D (Do), C (Check) and A (Act) cycle. They can be jointed in a single Integrated Management System (IMS) due implementing these standards in parallel requires many duplicate management tasks.
\end{abstract}

Design/methodology/approach - This article presents a literature review, which aims to analyse the scientific publications on the IMS theme and identify research opportunities. We used the EndNote X7 software (trial version) to identify, select, and index scientific articles. Our search presents five steps: (1) Definition of the research, (2) Search in the database, (3) Primary triage, (4) Search for the resulting, (5) Results, trends and suggestions

Findings - We pointed out in articles' portfolio: the country of the first author, number of articles per year, number of articles published by each journal, number of articles per author, and some benefits and difficulties in IMS implementation.

Research limitations/implications - Limitations of this article include the bibliometric criteria, i.e. the search options originally defined by the researchers. Other approaches could have been explored in the bibliometric such as the methodological approaches of the articles in the portfolio, detailing the types of qualitative and quantitative studies, for example. Moreover, this kind of research demands updates constantly due the dynamic of scientific publications, in this area, around the world.

Practical implications - The article provides a big picture for the adoption of integrated practices in management systems, as well as some drivers and obstacles for IMS implementation.

Originality/value - We highlighted the importance of strategically positioning of the IMS within the organization involving entire product chain and stakeholders.

Keywords: Integrated Management Systems; ISO 9001; ISO 14001; OHSAS 18001. 


\section{INTRODUCTION}

Over the last two decades, the number of international Management System Standards has grown rapidly. Since the introduction of the ISO 9001 Quality standard in 1987, other standards have been developed including that for Environmental Management (ISO 14001), Occupational Health and Safety Assessment Standard (OHSAS 18001), and Corporate Social Responsibility (AA1000) (Rocha et al., 2007).

ISO 9001 is a Quality Management System that focuses on operational efficiency and is organized in the form of requirements. Its objective is to increase customer satisfaction by ensuring that products meet clients' real needs. (Terziovski et Power, 2002, Lo et al., 2009, BayoMoriones et al., 2011).

To reduce the negative environmental impacts and maximize the positive, the Environmental Management System based on the ISO 14001 standard establishes a set of responsibilities, practices, procedures, policies, reviews, processes and resources that are required for its implementation. An Environmental Management System brings a production process into accordance with an environmental policy, enables the implementation of sustainable processes, reduces costs through better use of natural resources and applies the concepts of cleaner production (Arimura et Akira, 2008, Bogner, Bansal, 2007, Campos, Melo, 2008).

The Occupational Health and Safety Assessment Standard (OHSAS) is a systematic and proactive way to face the challenges of reducing risks and problems into the workplace. In this context, OHSAS 18001 specifies the requirements for a health and safety management system through procedures, policies, goals and objectives, planning, identification and monitoring the risk of accidents, seeking compliance with legal requirements (Rocha, 2010, Vinodkumar et Bhasi, 2011, Zwetsloot, 2003).

Companies have expressed increasing interest in the integration of Quality Management, Environmental and Occupational Health and Safety systems, respectively, ISO 9001, ISO 14001 and OHSAS 18001(Zeng et al., 2007). However, implementing these standards in parallel requires many duplicate management tasks (Fresner et Engelhardt, 2004).

Based on common definitions of management standards the ISO 9001, ISO 14000 and OHSAS 18001 systems are part of an organizational system used to implement their policies and manage their aspects and impacts. They are designed to provide elements of a management model in conjunction with other management requirements, since the structures of the management standards are similar and can be combined in a single management model, organized with a basis in the P (Plan), D (Do), C (Check) and A (Act) cycle. That is, continuous improvement is at the core of this methodology (Labodová, 2004, Pombo et Magrini, 2008).

The Management Systems (MS) have the following structure in common: (1) Management Policy, (2) Planning (3), Implementation and Operation, (4) Performance Evaluation, (5) Improvement, and (6) critical analysis. Although each management system standard has specific requirements, these six categories can be adopted to guide the integration of the standards. All of these MS require the definition of roles, responsibilities, written procedures and personnel training, with everything focused on continuous improvement (Wright, 2000, Zeng et al., 2007). They can thus be integrated on different levels (Jørgensen et al., 2006). Combining them in a single Integrated Management System (IMS) significantly reduces costs, which is directly related to the size of the organization and the nature of its activity (Wright, 2000).

Abad et al. (2014) based on a literature review, conducted a study which purpose was to analyse and empirically characterize the integration levels of IMS adopted by Spanish certified firms (ISO 9001, ISO 14001 and OHSAS 18001). Abad et al. (2014) did a review about taxonomies used by several authors with two, three and four level of analysis. They state that the most part of the authors propose taxonomies of three levels (Beckmerhagen et al., 2003, Bernardo et al., 2009, Ferguson et al., 2002, Jørgensen, 2008, Seghezzi, 1997). Abad et al. (2014) showed the usefulness of their taxonomic proposal for managers by exploring the relationship between the integration level achieved and subsequent corporate benefits, as follows: level 1 (documental harmonization), level2 (partial integration) and level 3 (full integration).

Abad et al. (2014) considered the impact of IMS on Internal benefits linked to the firm, and the external benefits, which are oriented to market. Results reveal that significant heterogeneity across integration levels is concentrated in the group of internal benefits, e.g., reduction in bureaucracy, reduction of the costs of internal audits. This indicates that managers perceive the IMS as a process that significantly enhances organizational and operational business areas. The managers whose companies achieve partial and full integration perceive that the IMS significantly increased the capacity to achieve the objectives of the business, in comparison with the managers of companies who achieve the level of documental harmonization. Abad et al. (2014) report a positive relationship between the integration level 
achieved and corporate benefits. Organizations achieving greater integration levels show the highest results, and the degree of perceived benefits systematically decreases according to the level of integration.

Simon et al., (2012) conducted a study to evaluate the difficulties that some companies face during the integration of the Management Systems. They studied the implementation of different standards during a period of four years - and conducted two empiric studies, one in 2006 and another in 2010. These studies were based on a survey conducted at companies in Catalonia, Spain that have more than one MS. It allowed the analysis of the integration level of different MS elements. Simon et al. (2012) adopted the Bernardo et al. (2009) classification for the levels of integration: "non integration," "partial integration" and "full integration." Comparing the levels of integration of 2006 and 2010 , the levels of "non-integration" increased (11\%-16\%) and those of "full integration" increased (42\%-62\%), while the level of "partial integration" decreased $(47 \%-22 \%)$. In 2006 , the most cited difficulties by companies in relation to integration of their MS were the lack of human resources, followed by the lack of technological and administrative support. In 2010, the most cited difficulty continued to be the lack of human resources, followed by a lack of employee motivation, and collaboration of the department. These results show the importance of motivating human resources, to reach a successful integration of the systems.

In relation to the benefits of integration of the MS, Simon et al. (2012) show only the results from 2010, because the benefits of integration were not included as a question in the 2006 study. Some of the most positive points are simplification of the task (documentation, requirements), increased organizational efficiency, better use of the results of internal and external audits and improved image of the company.

Bernardo et al. (2012) also investigated the difficulties found in the integration process and the level of system integration achieved. They investigated a sample of 362 organizations registered, at least, to both ISO 9001:2000 and ISO 14001:2004. As result, the organisations with three implemented management systems showed difficulties in the integration process that influence the level of integration, while this relationship is not significant for those organisations with two MS.

The IMS is perceived as a symbol for success and a prerequisite for survival, and (Jørgensen et al., 2006) added that to create competitive advantages for the organization and contribute to sustainable development, the IMS has to be expanded to include the entire product chain and all (Zeng et al., 2007). The IMS translates itself into a significant competitive advantage for organizations that generally have a very competitive market shares, characterized by intense competitiveness, constant technological progress, new market requirements, and scarce natural resources (Oliveira, 2013).

The challenge of integration is to overcome the grouping of requirements and achieve the mindset of synergy, this means that focus on the customer, environment, health, safety and social responsibility must be balanced in order to serve stakeholders (Jørgensen et al., 2006).

The management systems standards such as ISO 9001, ISO 14001 and OHSAS 18001 are developing toward a higher degree of compatibility. Nevertheless, different levels of integration of these systems are found. To improve this process, it is essential to promote interrelations between the areas to attain a holistic view that considers the entire product chain and all the stakeholders (Jørgensen, 2008).

This study utilized a bibliometric survey that allows the identification of specific research gaps, i.e., areas where further research is needed. Thus, this article analyses publications about Integrated MS and identifies opportunities for research.

We adopted the following structure in this article: (1) Introduction, (2) Methodological Procedures, (3) Results and Discussion, and the (4) Conclusions.

\section{METHODOLOGICAL PROCEDURES}

This paper presents a literature review, which aims to analyse the publications on the IMS theme and identify research opportunities. We used the EndNote X7 software to identify, select, and index scientific articles. Our search presents five steps (Figure 1).

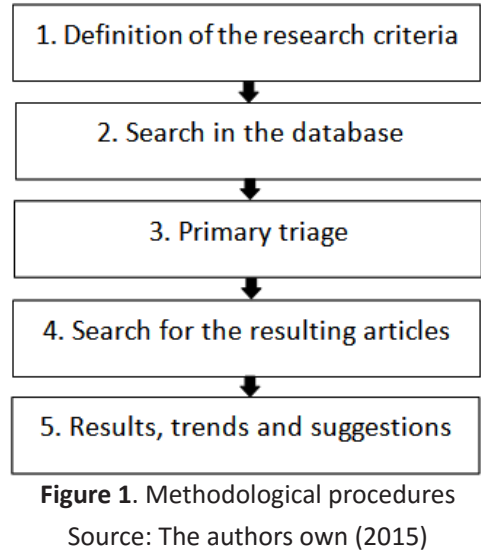

(1) Definition of the research criteria. Databases, keywords and period (in years) for the search. We chose: Scopus, Web of Science and Science Direct. Keywords "ISO 14001", "ISO 9001" and "OHSAS 18001". The period defined for the survey was from 2002 until 2013.

(2) Search in the databases. In the Web of Science, we selected the field "Topic" with the terms "ISO 14001", 
Brazilian Journal of Operations \& Production Management

Volume 13, Número 2, 2016, pp. 184-193

DOI: 10.14488/BJOPM.2016.v13.n2.a5

"ISO 9001" and "OHSAS 18001". The period was "2002 to date". In Scopus, we entered "ISO 14001", "ISO 9001" and "OHSAS 18001" selecting only "Article", "Title", "Abstract and Keywords". The period was "2002 to date", and area "Physical Sciences". In the Science Direct we selected "Advanced Search", "Journals", and we input the terms "ISO 14001", "ISO 9001, OHSAS 18001", in "Title", "Abstract", "Keywords" and selected "Engineering and Environmental Sciences", and "2002 to 2013" as the period of the search.

(3) Primary triage. We retrieved 88 articles, but within this universe, there were excerpts from books, articles outside the period (2002 to 2013) and many repeated registers, so, we conducted a primary triage, remaining 48 articles. We read the titles and abstracts and removed that were outside the scope of the research, remaining 37 articles (some articles did not have free access or were unavailable).
(4) Portfolio of articles. We retrieved 22 articles and extracted main ideas.

(5) We present some results and suggestions for future research.

\section{RESULTS AND DISCUSSION}

In this topic, we will present the result of the analysis in the portfolio. In addition to the literature review, we conducted a systematic analysis to identify features of interest to the topic IMS in the portfolio, and in some articles cited by the portfolio authors. It allowed identifying opportunities for research in this theme.

Table 1 presents the portfolio articles, authors, publication year, title and journal.

Table 1. Twenty-two articles of the portfolio

\begin{tabular}{|c|c|c|}
\hline N. & Authors/Year & Title/Journal \\
\hline 1 & $\begin{array}{l}\text { Bamber C. J., Sharp J. M., Castka } \\
\text { P. (2004) }\end{array}$ & $\begin{array}{l}\text { Third party assessment: the role of the maintenance functions in an integrated } \\
\text { management system. Journal of Quality in Maintenance Engineering. }\end{array}$ \\
\hline 2 & Celik M. (2009) & $\begin{array}{l}\text { Establishing an integrated process management system (IPMS) in ship management } \\
\text { companies. Expert Systems with Applications. }\end{array}$ \\
\hline 3 & $\begin{array}{l}\text { Izeppe F.R. et Oliveira, O. J. de } \\
\text { (2013) }\end{array}$ & $\begin{array}{l}\text { Guidelines for the collective and semi-presence-based implementation of certifiable } \\
\text { management systems. Gestão \& Produção. }\end{array}$ \\
\hline 4 & Jørgensen T.H. (2008) & $\begin{array}{l}\text { Towards more sustainable management systems: through life cycle management and } \\
\text { integration. Journal of Cleaner Production. }\end{array}$ \\
\hline 5 & $\begin{array}{l}\text { Jørgensen T. H., Remmen A., } \\
\text { Mellado M. D. (2006) }\end{array}$ & $\begin{array}{c}\text { Integrated management systems-three different levels of integration. Journal of Cleaner } \\
\text { Production. }\end{array}$ \\
\hline 6 & $\begin{array}{l}\text { Karapetrovič S. et Casadesús M. } \\
\qquad(2009)\end{array}$ & $\begin{array}{l}\text { Implementing environmental with other standardized management systems: scope, } \\
\text { sequence, time and integration. Journal of Cleaner Production }\end{array}$ \\
\hline 7 & Kisela T. (2010) & $\begin{array}{l}\text { Applications of the fractional calculus: on a discretization of fractional diffusion equation } \\
\text { in one dimension. Communications. }\end{array}$ \\
\hline 8 & $\begin{array}{l}\text { Maekawa R., Carvalho M.M., } \\
\text { Oliveira, O. J. de (2013) }\end{array}$ & $\begin{array}{l}\text { Study on ISO } 9001 \text { certification in Brazil: mapping the motivations, benefits, and } \\
\text { difficulties. Gestão \& Produção. }\end{array}$ \\
\hline 9 & $\begin{array}{l}\text { Mendes P., Santos A.C., Nunes } \\
\text { L.M., Teixeira M.R. (2013) }\end{array}$ & $\begin{array}{l}\text { Evaluating municipal solid waste management performance in regions with strong } \\
\text { seasonal variability. Ecological Indicators. }\end{array}$ \\
\hline 10 & $\begin{array}{l}\text { Merlin F.K., Pereira V.L.D.V, } \\
\text { Pacheco Júnior W. (2012) }\end{array}$ & $\begin{array}{c}\text { Sustainable development induction in organizations: a convergence analysis of ISO } \\
\text { standards management tools' parameters. Journal of Prevention, Assessment and } \\
\text { Rehabilitation. }\end{array}$ \\
\hline 11 & Oliveira, O. J. de (2013) & $\begin{array}{l}\text { Guidelines for the integration of certifiable management systems in industrial } \\
\text { companies. Journal of Cleaner Production. }\end{array}$ \\
\hline 12 & Pheng L.S. et Kwang G.K. (2005) & $\begin{array}{l}\text { ISO 9001, ISO } 14001 \text { and OHAS } 18001 \text { management systems: integration, costs and } \\
\text { benefits for construction companies. Architectural Science. }\end{array}$ \\
\hline 13 & Pun K.F. et Hui I.K. (2002) & $\begin{array}{l}\text { Integrating the safety dimension into quality management systems: a process model. } \\
\text { Total Quality Management }\end{array}$ \\
\hline 14 & Qi G., Zeng S., Yin H., Lin H. & $\begin{array}{l}\text { ISO and OHSAS certifications How stakeholders affect corporate decisions on } \\
\text { sustainability. Management Decision }\end{array}$ \\
\hline 15 & Qi L., Qingling D., Wei S., Jine Z. & $\begin{array}{l}\text { Modeling of Risk Treatment Measurement Model under Four Clusters Standards (ISO } \\
\text { 9001, 14001, 27001, OHSAS 18001). Procedia Engineering }\end{array}$ \\
\hline 16 & Salomone R. (2008) & $\begin{array}{c}\text { Integrated management systems: experiences in Italian organizations. Journal of Cleaner } \\
\text { Production }\end{array}$ \\
\hline 17 & $\begin{array}{c}\text { Santos G., Mendes, F., Barbosa } \\
\text { J. (2011) }\end{array}$ & $\begin{array}{c}\text { Certification and integration of management systems: the experience of Portuguese } \\
\text { small and medium enterprises. Journal of Cleaner Production }\end{array}$ \\
\hline 18 & Shaw O. (2004) & Hot tips for implementing an integrated management system. Engineering Management \\
\hline 19 & Singh S. (2011) & $\begin{array}{c}\text { An integrative approach to management systems and business excellence. African } \\
\text { Journal of Business Management }\end{array}$ \\
\hline 20 & $\begin{array}{l}\text { Zeng S.X., Shi, J.J., Lou G.X. } \\
\text { (2007) }\end{array}$ & $\begin{array}{l}\text { A synergetic model for implementing an integrated management system: an empirical } \\
\text { study in China. Journal of Cleaner Production }\end{array}$ \\
\hline 21 & $\begin{array}{l}\text { Zeng S.X., Tam C.M., Tam V.W.Y } \\
\text { (2010) }\end{array}$ & $\begin{array}{c}\text { Integrating Safety, Environmental and Quality Risks for Project Management Using a } \\
\text { FMEA Method. Engineering Economics }\end{array}$ \\
\hline 22 & $\begin{array}{l}\text { Zeng S.X., Tam V.W.Y., Le K.N. } \\
\text { (2010) }\end{array}$ & $\begin{array}{c}\text { Towards Effectiveness of Integrated Management Systems for Enterprises. Engineering } \\
\text { Economics }\end{array}$ \\
\hline
\end{tabular}


In Table 2 we considered the five most cited authors, among the authors of the portfolio (we classified only the 1st. author in each article). First, we highlight Karapetrovič S. and Zeng S.X., both with 19 citations.

Table 2. Five most cited authors in the portfolio

\begin{tabular}{cc}
\hline First author & Number of citations \\
\hline Karapetrovič, S. & 19 \\
Zeng, S.X. & 19 \\
Jørgensen, T. H. & 16 \\
Salomone, R. & 06 \\
Oliveira, O. J. de & 05 \\
\hline
\end{tabular}

Source: The authors own (2015)

Although Wilkinson G. and Bamber C.J. do not appear among the authors of the 22 articles in the portfolio, the portfolio authors cite them, 11 and 9 times, respectively.

We present (Table 3) another classification, considering the articles cited in the portfolio.

Table 3. Two most cited articles in the portfolio

\begin{tabular}{|c|c|c|c|}
\hline N. & Author/Year & Article Title & Citations \\
\hline 1 & $\begin{array}{l}\text { Jørgensen } \\
\text { T.H., Remmen } \\
\text { A., Mellado } \\
\text { M.D. (2006) }\end{array}$ & $\begin{array}{c}\text { Integrated } \\
\text { management } \\
\text { systems-three } \\
\text { different levels } \\
\text { of integration. } \\
\text { Journal of Cleaner } \\
\text { Production. }\end{array}$ & 08 \\
\hline 2 & $\begin{array}{l}\text { Zeng S.X., Shi } \\
\text { J.J., Lou G.X. } \\
\text { (2007) }\end{array}$ & $\begin{array}{l}\text { A synergetic model } \\
\text { for implementing } \\
\text { an integrated } \\
\text { management system: } \\
\text { an empirical study } \\
\text { in China. Journal of } \\
\text { Cleaner Production }\end{array}$ & 04 \\
\hline
\end{tabular}

Source: The authors own (2015)

The most cited article, with eight citations, entitled "Integrated management systems - three different levels of integration" was written by Jørgensen et al. (2006) and published in the Journal of Cleaner Production (Table 3). These authors discuss the different levels of integration of the management systems (ISO 9001, ISO 14001, OHSAS 18001 and SA 8000), which due to the tendency toward increasing compatibility between systems has stimulated discussions about how to understand the different aspects of integration. The focus of this article is to discuss three levels of integration ( 1 - compatibility, 2 - coordination, 3 strategy), which encompasses the increased compatibility of system elements, the coordination of generic processes for insertion of IMS in the learning culture and continuous improvements. The author compares the development of IMS in Denmark and Spain and highlights the need to broaden the focus of the organization to the entire product chain and all the stakeholders.

Moreover, according to Table 3, the second most cited article was written by Zeng et al. (2007) "A synergetic model for implementing an integrated management system: an empirical study in China". Thus, the authors propose a model of multi-level synergy for effective implementation of IMS (strategic synergy, organizational structural-resourcecultural synergy, and documentation synergy) for an effective implementation of IMS.

Zeng et al. (2007) affirm that IMS is seen as a symbol of success and a prerequisite for the survival of companies. However, the difficulty is to operate multiple management systems in parallel, and seek alignment with the organization's strategy. The main problems of the companies that operate parallel management systems include complexity and reduced efficiency in management, cultural incompatibility, resistance from employees and increased management costs. The survey also examined the internal and external factors that affect the implementation of IMS. The internal factors include: (1) human resources, (2) organizational structure, (3) company culture, (4) understanding and perception. The external factors are following: (1) technical guidance, (2) certification agencies, (3) stakeholders and customers and (4) the institutional environment.

In Figure 2 we present the country of origin of the first author with the number of articles. There is predominance of authors from China, totaling four: (1) Zeng S.X. (2) Pun K.F. (3) Qi G. (4) Qi L. There are six articles from this country: Zeng S.X. has three articles, and the remaining three authors, each has one article. Brazil is the country with the second highest number of articles, also with four authors, but each author has only one article in the portfolio: (1) Izeppe F.R. (2) Oliveira, O. J. de (3) Merlin F.K. and (4) Maekawa R. Portugal follows with two authors, (1) Santos G. and (2) Matias P., each author has one article.

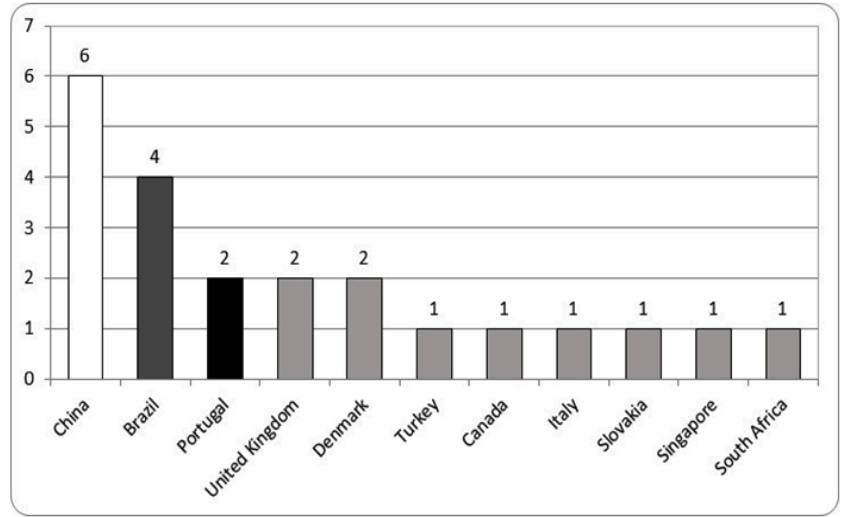

Figure 2. Country of the first author Source: The authors own (2015) 
One can observe, based on Figure 3 that in the discussion of the theme "Integrated Management Systems" from 2002 until 2013, there was no significant variation in the number of publications on this subject. However, in 2013, the number of publications rose significantly, from 2 articles in 2012 to 5 in 2013.

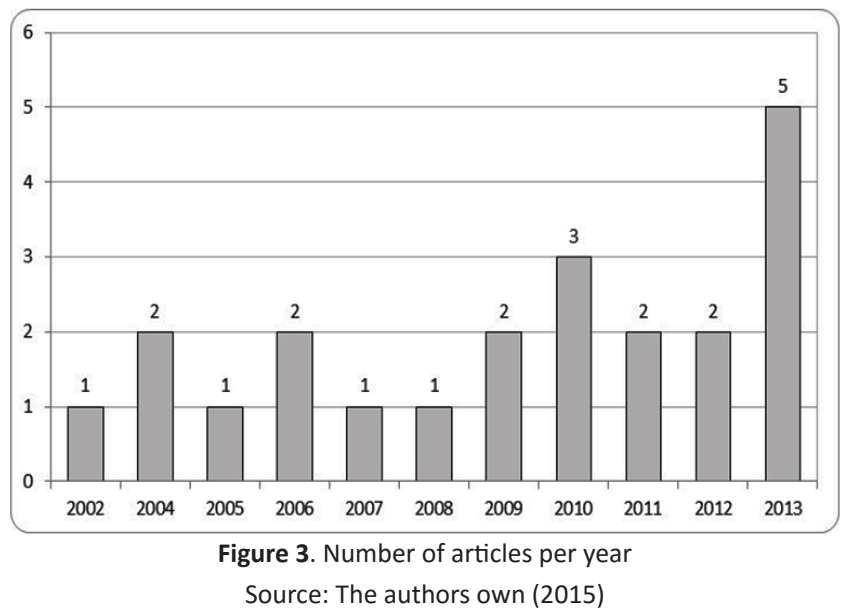

Figure 4 shows the number of articles published by each journal in the portfolio. As indicated, the Journal of Cleaner Production (JCP) leads with 7 articles in the portfolio. In second place, there are two journals, Gestão \& Produção and Engineering Economics with 2 articles each. Remaining 11 journals with 1 article each, Ecological Indicators, Engineering Management, Scientific Letters of Zilina, Total Quality Management, Architectural Science Review (ASR), Management Decision, Procedia Engineering, Work, Journal of Quality in Maintenance Engineering (JQME), African Journal of Business Management (AJBM), and Expert Systems with Applications (ESA).

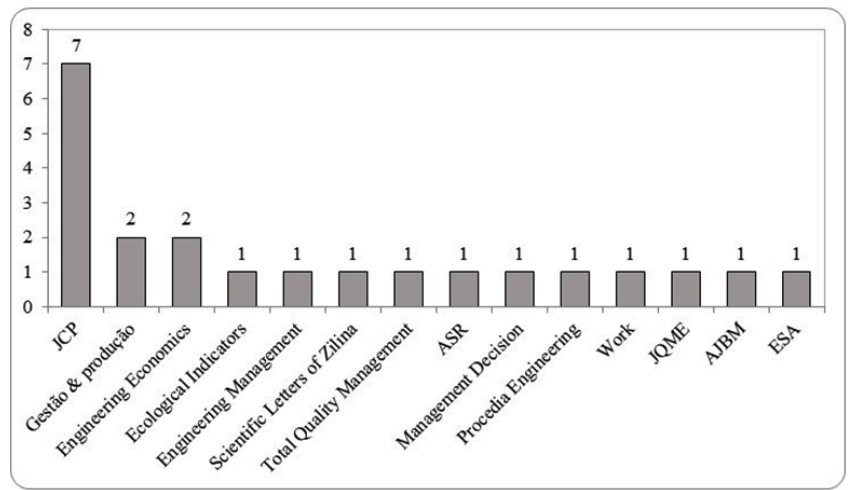

Figure 4. The number of articles published by each journal Source: The authors own (2015)

Figure 5 shows the number of articles per author (we consider only the first author). The author with the most articles is the Chinese Zeng S.X. with three articles. In second place, there is the Danish Jørgensen T.H. with two articles. All the other authors have only one article in the portfolio.

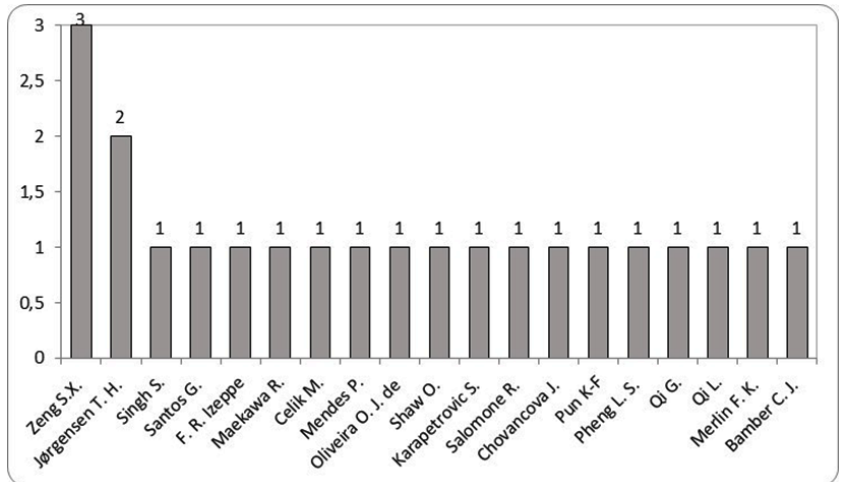

Figure 5. Number of articles per author Source: The authors own (2015)

We identified many studies in the portfolio that investigate difficulties and benefits of the implementation of IMS, and we present some of them in Table 4.

Each management system requires a considerable amount of documentation, written procedures, checking, control forms and other paper work, according to Zeng et al. (2007). Information difficulties, such as bottlenecks, can pre-exist due to communication problems that occur in dispersed systems. Nevertheless, these systems share common goals that can be integrated into a single system, which avoids reworking and an increase of documents and information channels (Simon, 2012).

Zeng et al. (2007) stated that operating multiple systems effectively is difficult. For example, Fresner et Engelhardt (2004), Holdsworth, (2003) and Jørgensen et al. (2006) found that it was difficult and costly to operate a number of management systems in parallel. Zeng et al. (2010) declared that integration is a growing need into companies, and this is often due not solely to the numerous difficulties that they encounter in handling different management systems individually, but also to the substantial advantages to be gained from integration. These advantages include reducing various expenditures such as staffing for auditing, and avoiding strategies and policies that are not integrated and even conflicting at some times. Zeng et al. (2010) affirm that it is challenging to deal with three separate management systems and ensure their alignment with the organization's strategy.

According to Oliveira (2013) (p. 124), "Multiple certifiable management systems can function separately. However, they are counterproductive, difficult to manage, and involve employees who invariably question whether they should prioritize the productive processes or the excessive bureaucracy they [the management systems] generate". However, the integration process is complex; according to Jørgensen et al., (2006) the IMS should consider the whole product chain and all the stakeholders. In addition, for that, the IMS should expand, reaching economic benefits 
(competitive advantage to the organization) social and environmental, contributing to sustainable development.

Table 4. Benefits and difficulties in IMS implementation.

Authors, benefits and difficulties to implement IMS

\section{Benefits}

Zeng et al. (2010) - Simplification of the certification process, reducing management costs and documents. Santos, Mendes, Barbosa (2011) - Reduced costs, improved employee-training, easer to comply with the legislation.

Simon et al. (2012) - Increased internal cohesion, better use of systems, focusing on organizational strategy.

Matias et Coelho (2002) - A joint approach to quality, environmental responsibility and protection of the workforce.

Salomone (2008) - Optimization/unification of internal and external audit, reduction of documentation, timesaving, optimization/unification of training activities, reduction of bureaucracy.

Karapetrovič et Willborn (1998b), Wilkinson et Dale (1999), Douglas et Glen (2000), Renzi et Capelli (2000), Zutshi et Sohal (2005), Rocha, Searcy et Karapetrovič (2007), Salomone (2008), Asif et al. (2009, 2010), Khanna, Laroiya, Sharma (2010), Simon et al. (2012), Zeng et al. (2010) - Decreased costs, operational improvements, better external image, increased customer satisfaction and employee motivation.

\section{Difficulties}

Salomone (2008) - Risk of not assigning the appropriate level of importance to each variable: quality, environment, safety. Difficulties in organizing an IMS.

Santos, Mendes, Barbosa (2011) - Insufficient integration of standards, very long time for the process integration, difficulty in the training of staff and in changing the organizational culture.

Zutshi et Sohal (2005) and Asif et al. (2009) - Lack of qualified human resources and government support.

Holdsworth (2003) - Conflict of quality management procedures with similar procedure for safety and risk management.

Karapetrovič et Willborn (1998a), Zutshi et Sohal (2005), Zeng, Shi, Lou (2007) and Asif et al. (2009) - Internal organizational issues such as departmentalization of functions, lack of resources and lack of individual preoccupation of the people involved.

Matias et Coelho (2002), Zutshi et Sohal (2005), Zeng, Shi, Lou (2007) - Lack of attitude and motivation of people.

Source: The authors own (2015)

The Integrated Management Systems show, especially in the international review, many benefits in terms of cost reduction, because these IMS concentrate management efforts into one system, integrating what were three separate initiatives. Nevertheless, Brazilian companies have difficulties in conducting this integration. This is reflected in the small number of Brazilian publications in recognized international journals about the implementation of IMS, which is thus a research opportunity.

In practice, the certification of the management systems ISO 9001, ISO 14001 and OHSAS 18001 represents an important competitive advantage for companies. However, one of the biggest barriers to the implementation of these systems are the high costs. For this reason Brazilian researchers Izeppe et Oliveira (2013), and Pinto et al. (2006), suggest that the collective and semi-face-to-face development of these systems - with no active participation of a consultant or specialist in these systems directly at the company - can be one way to reduce these costs.

In a survey of 121 Brazilian companies, Pinto et al. (2006) investigated the relationship of the practices of ISO 9001, ISO 14001 and OHSAS 18001 systems, and concluded that there is no effective use of IMS, since there are few companies in the sample that have all three systems simultaneously: $13.61 \%$ have ISO 14001 certification, and $8.38 \%$ have OHSAS 18001.

\section{CONCLUSION}

The aim of this study was to analyze publications about Integrated Management Systems and identify research opportunities. We analyzed articles from 2000 to 2013, and identified a tendency to focus on the difficulties and benefits of implementing the IMS.

We highlighted the importance of strategically positioning of the IMS within the organization, which is a prerequisite for implementing any management system especially when considering the integration of Quality, Environmental, Occupational Health and Safety standards, and confirming their relevance by involving stakeholders.

Limitations of this article include the bibliometric criteria, i.e. the search options originally defined by the researchers. Other approaches could have been explored in the bibliometric such as the methodological approaches of the articles in the portfolio, detailing the types of qualitative and quantitative studies.

This literature review contributed to a better understanding of academic research related to IMS, and identifies the need to further study this subject with a strategic approach.

The research about IMS in Brazil still is incipient, there is a limited amount of articles written in English, and thus, with a divulgation limited to the international academic community. In general, we found in the literature review a growing concern from the academic and business environment, for the integration of Management Systems such as Quality, Environmental and Occupational Health and Safety. 
Brazilian Journal of Operations \& Production Management

Volume 13, Número 2, 2016, pp. 184-193 DOI: 10.14488/BJOPM.2016.v13.n2.a5

\section{REFERENCES}

Abad, J., Dalmau, I. and Vilajosana, J. (2014), "Taxonomic proposal for integration levels of management systems based on empirical evidence and derived corporate benefits", Journal of Cleaner Production, 78, pp. 164-173.

Arimura, T. H., Akira, H. and Hajime K. (2008), "Is a voluntary approach an effective environmental policy instrument? A case for environmental management systems", Journal of Environmental Economics and Management, 55, pp. 281295.

Asif, M., Bruijn E. J. D., Fisscher, O. A. M., Searcy, C. and Steenhuis, H. J. (2009) "Process embedded design of integrated management systems", International Journal of Quality \& Reliability Management, 26, pp. 261-82.

Asif, M., Fischer, O. A. M., Bruijn, E. J. de and Pagell, M. (2010), "An examination of strategies employed for the integration of management systems", The TQM Journal, 22, pp. 648-69.

Bamber, C. J., Sharp, J. M. and Castka, P. (2004), Third party assessment: the role of the maintenance function in an integrated management system, Journal of Quality in Maintenance Engineering, 10:1, pp. 26-36.

Bamber, C. J., Sharp, J. M. and Hides, M. (2002), "The role of the maintenance organization in an integrated management system", Managerial Auditing Journal, 17, pp. 20-25.

Bayo-Moriones, A., Merino-Díaz-De-Cerio, J., EscamillaDe-León, S. A., and Selvam, M. R. (2011), "The impact of ISO 9000 and EFQM on the use of flexible work practices", International Journal of Production Economics, 130, pp. 3342.

Beckmerhagen, I. A., Berg, H. P., Karapetrovič, S. and Willborn, W.O. (2003), "Integration of management systems: focus on safety in the nuclear industry", International Journal of Quality \& Reliability Management, 20:2, pp. 209-223.

Bernardo, M., Casadesús, M., Karapetrovič, S. and Heras, I. (2012), "Do integration difficulties influence management system integration levels?" Journal of Cleaner Production, 21, pp. 23-33.

Bernardo, M., Casadesús, M., Karapetrovič, S. and Heras, I. (2009), "How integrated are environmental, quality and other standardized management systems? An empirical study", Journal of Cleaner Production, 17:8, pp. 742-750.

Bogner, W. C. et Bansal, P. (2007), "Knowledge management as the basis of sustained high performance", Journal of Management Studies, 44, pp. 165-188.

Campos, L. M. D. S. et Melo, D. A. D. (2008), “Indicadores de desempenho dos Sistemas de Gestão Ambiental (SGA): uma pesquisa teórica", Produção, 18, pp. 540-555.
Celik, M. (2009), “Establishing an integrated process management system (IPMS) in ship management companies", Expert Systems with Applications, 36, pp. 81528171.

Douglas, A. et Glen, D. (2000), “Integrated management systems in small and medium enterprises", Total Quality Management, 11, pp. 686-690.

Ferguson, M. C., García, M. and Bornay, M. M. (2002), "Modelos de implantacion de los sistemas integrados de gestion de la calidad, el medio ambiente y la seguridade", Investigaciones Europeas de Dirección y Economía de la Empresa, 8:1, pp. 97-118.

Fresner, J. et Engelhardt, G. (2004), “Experiences with integrated management systems for two small companies in Austria", Journal of Cleaner Production, 12, pp. 623-631.

Holdsworth, R. (2003), "Practical applications approach to design, development and implementation of an integrated management system", Journal of Hazardous Materials, 14, pp. 193-205.

Izeppe, F. R. et Oliveira, O. J. (2013), “Guidelines for the collective and semi-presence-based implementation of certifiable management systems", Gestão \& Produção, 20, pp. 603-613.

Jørgensen, T. H. (2008), "Towards more sustainable management systems: through life cycle management and integration", Journal of Cleaner Production, 16, pp. 10711080.

Jørgensen, T. H., Remmen, A. and Mellado, M. D. (2006), "Integrated management systems-three different levels of integration", Journal of Cleaner Production, 14, pp. 713-722.

Karapetrovič, S. et Casadesús, M. (2009), “Implementing environmental with other standardized management systems: scope, sequence, time and integration", Journal of Cleaner Production, 17, pp. 533-540.

Karapetrovič, S. et Willborn, W. (1998a), "Integrated audit of management systems", International Journal of Quality \& Reliability Management, 15, pp. 694-711.

Karapetrovič, S. et Willborn, W. (1998b), "Integration of quality and environmental management systems", The TQM Magazine, 10, pp. 204-213.

Khanna, K. H., Laroiya, S. C. and Sharma, D. D. (2010), "Integrated management systems in Indian manufacturing organizations: some key findings from an empirical study", The TQM Journal, 22, pp. 670-86.

Kisela, T. (2010), "Applications of the fractional calculus: on a discretization of fractional diffusion equation in one dimension", Communications, Vol. 1, pp. 5-11. 
Brazilian Journal of Operations \& Production Management Volume 13, Número 2, 2016, pp. 184-193

DOI: 10.14488/BJOPM.2016.v13.n2.a5
Labodová, A. (2004), "Implementing integrated management systems using a risk analysis based approach", Journal of Cleaner Production, 12, pp. 571-580.

Lo, C. K. Y., Yeung, A. C. L. and Cheng, T. C. E. (2009), "ISO 9000 and supply chain efficiency: empirical evidence on inventory and account receivable days", International Journal of Production Economics, 118, pp. 367-374.

Maekawa, R., Carvalho, M. M. de and Oliveira, O. J. de. (2013), "Study on ISO 9001 certification in Brazil: mapping the motivations, benefits, and difficulties", Gestão \& Produção, 20:4, pp. 763-779.

Matias, J. C. O. et Coelho, D. A. (2002), "The integration of the standards systems of quality management, environmental management and occupational health and safety management", International Journal of Production Research, 40, pp. 3857-3866.

Mendes, P., Santos, A. C., Nunes, L. M. and Teixeira, M. R. (2013), "Evaluating municipal solid waste management performance in regions with strong seasonal variability", Ecological Indicators, 30, pp. 170-177.

Merlin, F. K., Pereira, V. L. D. do V. and Pacheco Júnior, W. P. (2012), "Sustainable development induction in organizations: a convergence analysis of ISO standards management tools' parameters", Work: A Journal of Prevention, Assessment and Rehabilitation, 41, pp. 2736-2743.

Oliveira, O. J. de (2013), "Guidelines for the integration of certifiable management systems in industrial companies", Journal of Cleaner Production, 57, pp. 124-133.

Pheng, L. S. et Kwang, G. K. (2005), “ISO 9001, ISO 14001 and OHSAS 18001 management systems: integration, costs and benefits for construction companies", Architectural Science Review, 48, pp. 145-151.

Pinto, S. H. B., Carvalho, M. M. and Ho, L. L. (2006), "Implementação de programas de qualidade: um survey em empresas de grande porte no Brasil", Gestão \& Produção, 13, pp. 191-203.

Pombo, F. R. et Magrini, A. (2008), “Panorama de aplicação da norma ISO 14001 no Brasil”, Gestão \& Produção, 15, pp. 1-10.

Pun, K. F. et Hui, I. K. (2001), “An analytical hierarchy process assessment of the ISO 14001 environmental management system", Integrated Manufacturing Systems, 12:5, pp. 333-345.

Pun, K. F. et Hui, I. K. (2002), "Integrating the safety dimension into quality management systems: a process model", Total Quality Management, 13, pp. 373-391.

Qi, G., Zeng, S., Yin, H. and Lin, H. (2013), "ISO and OHSAS certifications: How stakeholders affect corporate decisions on sustainability". Management Decision, 51, pp. 19832005.
Qi, L, Qingling D., Wei S. and Jine Z. (2012), “Modeling of Risk Treatment Measurement Model under Four Clusters Standards (ISO 9001, 14001, 27001, OHSAS 18001)", Procedia Engineering, 37, pp. 354-358.

Renzi, M. F. et Cappelli, L. (2000), "Integration between ISO 9000 and ISO 14000: opportunities and limits", Total Quality Management, 11, pp. 849-856.

Rocha, M., Searcy, C. and Karapetrovič, S. (2007), "Integrated sustainable development into existing management systems", Total Quality Management \& Business Excellence, 18, pp. 83-92.

Rocha, R. S. (2010), "Institutional effects on occupational health and safety management systems", Human Factors and Ergonomics in Manufacturing \& Service Industries, 20, pp. 211-225.

Salomone, R. (2008), "Integrated management systems: experiences in Italian organizations", Journal of Cleaner Production, 16, pp. 1786-806.

Santos, G., Mendes, F. and Barbosa, J. (2011), “Certification and integration of management systems: the experience of Portuguese small and medium enterprises", Journal of Cleaner Production, 19, pp. 1965-1974.

Seghezzi, H.D. (1997), "Business concept redesign”, Total Quality Management, 8 (2/3), pp. S36-S43.

Shaw, O. (2004), "Hot tips for implementing an integrated management system", Engineering Management Journal, Vol. 14, No.3, pp. 10-13.

Simon, A., Bernardo, M., Karapetrovič, S. and Casadesús, M. (2011), "Integration of standardized environmental and quality management systems audits", Vol. 19, No.3, Journal of Cleaner Production, pp. 2057-2065.

Simon, A., Karapetrovič, S. and Casadesús, M. (2012), "Evolution of Integrated Management Systems in Spanish firms", Journal of Cleaner Production, 23, pp. 8-19.

Singh, S. (2011), "An integrative approach to management systems and business excellence", African Journal of Business Management, 5, pp. 1618-1629.

Terziovski, M. et Power, D. (2002), “Increasing ISO 9000 certification benefits: A continuous improvement approach, International", Journal of Quality \& Reliability Management, 24, pp. 141-163.

Vinodkumar, M. N. et Bhasi, M. (2011), "A study on the impact of management system certification on safety management", Safety Science, 49, pp. 498-507.

Wilkinson, G. et Dale, B. G. (1999), "Integrated management systems: an examination of the concept and theory", The TQM Magazine, 11, pp. 95-104.

Wright, T. (2000), "IMS-Three into one will go! The advantages of a single integrated quality, health and safety, 
and environmental management system", The Quality Assurance Journal, 4, pp. 137-142.

Zeng, S. X., Shi, J. J. and Lou, G. X. (2007), "A synergetic model for implementing an integrated management system: an empirical study in China". Journal of Cleaner Production, 15, pp. 1760-1767.

Zeng, S. X., Tam, C. M. and Tam, V. W. Y. (2010), "Integrating Safety, Environmental and Quality Risks for Project Management Using a FMEA Method", Engineering Economics, 21:1, pp. 44-52.

Zeng, S. X., Xie, X. M., Tam, C.M. and Shen, L. Y. (2010), "An empirical examination of benefits from implementing integrated management systems (IMS)", Total Quality Management \& Business Excellence, 22, pp. 173-86.

Zutshi, A. et Sohal, A. S. (2005), "Integrated management system: the experiences of three Australian organisations", Journal of Manufacturing Technology Management, 16:2, pp. 211-232.

Zwetsloot, G. I. J. M. (2003), "From management systems to corporate social responsibility", Journal of Business Ethics, 44, pp. 201-208. 